\title{
Detection of Salmonella species in chicken carcasses using genus specific primer belong to invA gene in Sohag city, Egypt
}

\author{
Nahed Mahmoud Abdel-Aziz \\ Department of Food Hygiene, Faculty of Veterinary Medicine, Sohag University, Naser Street, Sohag, Egypt. \\ Corresponding author: Nahed Mahmoud Abdel-Aziz, e-mail: Nahedvet2012@yahoo.com \\ Received: 04-05-2016, Accepted: 18-08-2016, Published online: 22-10-2016
}

doi: 10.14202/vetworld.2016.1125-1128 How to cite this article: Abdel-Aziz NM (2016) Detection of Salmonella species in chicken carcasses using genus specific primer belong to invA gene in Sohag city, Egypt, Veterinary World, 9(10): 1125-1128.

\begin{abstract}
Aim: This study aimed to detect Salmonella species found as contaminants in chicken carcass (thigh, breast, wings, liver, and gizzard).

Materials and Methods: A total of 75 chicken samples including thigh, breast, wings, liver, and gizzard (15 of each) were collected from different markets in Sohag city for detection of Salmonella species by culture methods, biochemical tests, serology, and polymerase chain reaction.

Results: The overall incidence of Salmonella contamination of 75 examined samples was found to be $6.6 \%$ with the higher percentage of Salmonella being isolated from liver samples (13.3\%) followed by thigh, wings, gizzard (6.6\%) while breast show negative result.
\end{abstract}

Conclusion: Results in this study indicate that contamination of chicken carcass with Salmonella needs strict hygienic measures to prevent their transmission to human.

Keywords: chicken carcass, invA gene, Salmonella spp.

\section{Introduction}

Poultry meat constitutes a substantial portion of protein in this day diets; hence, it has an important share $(30 \%)$ in the world's total meat consumption [1]. The poultry meat is easy to prepare at home and widely used in restaurants and fast-food establishments [2]. Poultry products have always topped the incidence of salmonellosis in many developing countries including India, Egypt, Brazil, and Zimbabwe [3]. Salmonella often reach the carcasses from the intestinal tracts or fecal materials on feathers or feet. Particularly scalding, defeathering, evisceration, and giblet operations are the major points of spread in poultry processing plants [4].

There are several transmission routes for salmonellosis, but the majority of human infections are derived from the consumption of contaminated foods especially those of animal origin [5]. In human, Salmonella is the cause of two diseases called Salmonellosis: Enteric fever (typhoid), resulting from bacterial invasion of the blood stream, and acute gastroenteritis, resulting from a foodborne infection/ intoxication [6].

Polymerase chain reaction (PCR) technology is used for rapid detection [7] and increase the

Copyright: Nahed Mahmoud Abdel-Aziz. Open Access. This article is distributed under the terms of the Creative Commons Attribution 4.0 International License (http://creativecommons. org/licenses/by/4.0/), which permits unrestricted use, distribution, and reproduction in any medium, provided you give appropriate credit to the original author(s) and the source, provide a link to the Creative Commons license, and indicate if changes were made. The Creative Commons Public Domain Dedication waiver (http:// creativecommons.org/publicdomain/zero/1.0/) applies to the data made available in this article, unless otherwise stated. sensitivity of detection of Salmonella in food, environmental, and clinical samples. The invA gene is the target of many of these methods as it is found in all known serovars of Salmonella [8]. Furthermore, it codes for protein in the inner membrane of bacteria that are necessary for invasion of epithelial cells [9]. This study aimed to detect Salmonella spp. from poultry products using traditional detection methods as culturing, biochemical tests, serology, and PCR detection of $i n v A$ gene.

\section{Material and Methods}

\section{Ethical approval}

Not required for this study.

\section{Collection of samples}

A total of 75 samples were collected from different markets in Sohag city. The collected samples include thigh, breast, wings, liver, and gizzard (15 of each). The samples were transported immediately to the laboratory in the Faculty of Veterinary Medicine in Sohag University.

\section{Isolation of Salmonella species}

About $25 \mathrm{~g}$ of each sample was cut into small pieces using sterile forceps and scissors and blended for $2 \mathrm{~min}$ in sterile blender jar containing $225 \mathrm{ml}$ of buffered peptone water $(0.1 \%)$ as a pre-enrichment broth and incubated at $37^{\circ} \mathrm{C}$ for $24 \mathrm{~h}$. After incubation, $0.1 \mathrm{ml}$ of pre-enrichment culture was transferred into sterile tubes containing $10 \mathrm{ml}$ of Rappaport Vassiliadis broth (Lab M Ltd., UK), and the tubes were then incubated at $43^{\circ} \mathrm{C}$ for $24 \mathrm{~h}$. Thereafter, a loopful of each incubated tube was cultured on xylose lysine desoxycholate (Hi Media, India) agar plates and incubated 
for $24 \mathrm{~h}$ at $35^{\circ} \mathrm{C}$. Typical colony of salmonella appears as pink colonies with or without black centers.

\section{Identification of Salmonella spp.}

Identification was done morphologically by microscopical examination with Gram-stain.

\section{Biochemical identification}

Biochemical tests as triple sugar iron (Oxoid, $\mathrm{UK}$ ) reaction, urease test (Oxoid, UK), indole production, methyl red (Becton Dickinson) test, and simmons citrate (Titan media, India) test. Isolates proved biochemically to be Salmonella spp.

\section{Sereological identification}

Serological identification was done according to Kauffmann-White scheme [10] in the Food Hygiene Lab in the Faculty of Veterinary Medicine, Banha University, Egypt.

\section{Detection of invA gene using PCR}

Detection of the invasion gene (invA) was performed according to the primer sequence 5'GTGAAATTATCGCCACGTTCGGGCA'3 and 5'TCATCGCACCGTCAAAGGAACC'3 according to Shanmugasamy et al. [11]. The isolated colonies from samples were overnight cultured on nutrient agar (Oxoid) plates, one or two colonies were suspended in $20 \mathrm{ml}$ of sterile distilled water, and the suspension was then heated at $100^{\circ} \mathrm{C}$ for $20 \mathrm{~min}$. Accurately, $50-200 \mu \mathrm{l}$ of the culture was placed in Eppendorf tube and the DNA extraction occurred using QIA amp kit [12]. The amplification was performed on a thermal cycler (Mastercycler, Eppendorf, Hamburg, Germany). The PCR cycling protocol was applied as following: An initial denaturation at $94^{\circ} \mathrm{C}$ for $5 \mathrm{~min}$, followed by 35 cycles of denaturation at $94^{\circ} \mathrm{C}$ for $60 \mathrm{~s}$, annealing at $64^{\circ} \mathrm{C}$ for $30 \mathrm{~s}$, and extension at $72^{\circ} \mathrm{C}$ for $30 \mathrm{~s}$, followed by a final extension at $72^{\circ} \mathrm{C}$ for $7 \mathrm{~min}$. Finally, $5 \mu$ of each amplicon was electrophoresed in $1.5 \%$ agarose gel (Sigma, USA) and visualized under ultraviolet transilluminator. A 100 bp DNA ladder was used as a marker (Promega, USA) for PCR products.

\section{Results and Discussion}

Salmonella species is present in the examined chicken carcasses with percentage of $6.6 \%$, the highest level of contamination was present in liver with percentage of 13.3 followed by thigh, wings and gizzard $6.6 \%$, while breast samples free from Salmonella species. Owing to Salmonella serotypes, the rate of contamination with Salmonella enteritidis and Salmonella typhimurium was $2.7 \%$ and Salmonella Kentucky $1.3 \%$. The invA gene was used for specific identification of Salmonella species using PCR.

Meat and poultry products are recognized as the major sources for transmitting Salmonella species to human with $40 \%$ of the clinical cases attributed to the consumption of egg and poultry products [13]. In this study, the overall incidence of Salmonella contamination of examined samples was found to be $6.6 \%$ (Table- 1 ). These results closely agree with Akbar and Kumar [14], Karmi [15], Suwit et al. [16], and Pedro et al. [17]. Compared with other studies that evaluated chicken carcasses, the prevalence of Salmonella spp. In this study was lower than that recorded by Alali et al. [18], Jianghui et al. [19], Rodriguez et al. [20], and Jarquin et al. [21], whereas this result was higher than that obtained by Elgroud et al. [22]. On the opposite side, Cretu et al. [23] reported that some countries such as Sweden where poultry free from Salmonella, and this stage was reached after observing some governmental control programs and measures, applied by poultry breeders and meat processors.

Currently, Salmonella is detected by standard bacteriological, biochemical, and serological techniques. These techniques are generally time-consuming, tedious, and expensive [24]. Salmonella specific PCR with primers for invA gene is rapid, sensitive, and specific for detection of Salmonella in many clinical samples. The invA gene is carried on a region of the bacterial chromosome known as the Salmonella pathogenicity island 1 and encodes for protein in inner membrane of bacteria, which is necessary for invasion to epithelial cells for full virulence in Salmonella and is thought to trigger internalization required for invasion of deeper tissue [25].

Serological tests in this study revealed that the five isolates belonged to three different serotypes, Salmonella typhimurium 2 (2.7\%), Salmonella enteritidis 2 (2.7\%), and Salmonella kentucky 1 (1.3\%) (Table-2). The results of serological identification of Salmonella species in this study improve the result obtained by Ibrahim et al. [26] who found that the most common serotypes in carcasses surveyed were the main serotypes of Salmonella found in the literature associated with disease in humans, Salmonella enteritidis and typhimurium. Salmonella enterica serovar, Salmonella enteritidis, and Salmonella enterica serovar typhimurium are the most frequently isolated serovars from foodborne outbreaks worldwide [27]. Figure-1 showed confirmatory identification of Salmonella species by PCR method with genus specific primer called invA gene, using this method is accurate, rapid and less expensive. In conclusion, isolation of Salmonella carrying invasion invA gene in this study may indicate the poor sanitation of the

Table-1: Incidence of Salmonella contamination of the examined samples.

\begin{tabular}{lccc}
\hline Samples & $\begin{array}{c}\text { Number of the } \\
\text { examined samples }\end{array}$ & $\begin{array}{c}\text { Number of } \\
\text { the isolates }\end{array}$ & $\%$ \\
\hline Thigh & 15 & 1 & 6.6 \\
Breast & 15 & 0 & 0 \\
Wings & 15 & 1 & 6.6 \\
Liver & 15 & 2 & 13.3 \\
Gizzard & 15 & 1 & 6.6 \\
Total & 75 & 5 & 6.6 \\
\hline
\end{tabular}


Table-2: Serological identification of Salmonellae species.

\begin{tabular}{|c|c|c|c|c|c|}
\hline \multirow[t]{2}{*}{$\begin{array}{l}\text { Salmonella } \\
\text { serovar }\end{array}$} & \multirow[t]{2}{*}{$\mathbf{N}=75(\%)$} & \multirow[t]{2}{*}{ Sample } & \multirow[t]{2}{*}{ Group } & \multicolumn{2}{|c|}{$\begin{array}{l}\text { Antigenic } \\
\text { structure }\end{array}$} \\
\hline & & & & $\mathbf{0}$ & H \\
\hline $\begin{array}{l}\text { Salmonella } \\
\text { enteritidis }\end{array}$ & $2(2.7)$ & $\begin{array}{l}\text { Thigh, } \\
\text { liver }\end{array}$ & D1 & $1,9,12$ & $\mathrm{~g}, \mathrm{~m}$ \\
\hline $\begin{array}{l}\text { Salmonella } \\
\text { typhimurium }\end{array}$ & $2(2.7)$ & $\begin{array}{l}\text { Wings, } \\
\text { gizzard }\end{array}$ & $B$ & $\begin{array}{c}1,4,5 \\
12\end{array}$ & i: 1,2 \\
\hline $\begin{array}{l}\text { Salmonella } \\
\text { kentucky }\end{array}$ & $1(1.3)$ & Liver & C3 & 8,20 & i: Z6 \\
\hline
\end{tabular}

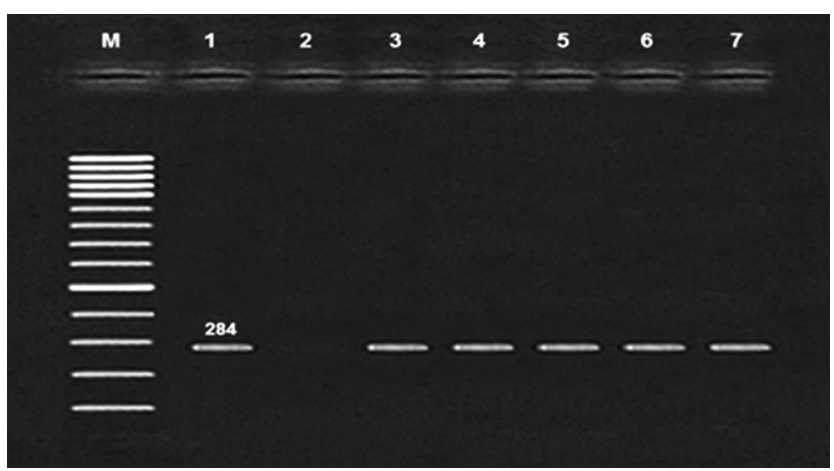

Figure-1: Agarose gel electrophoresis of polymerase chain reaction of invA gene (284 bp) for identification and characterization of Salmonella species. Lane M: 100 bp ladder as molecular size DNA marker. Lane 1: Control positive Salmonellae invA gene, Lane 2: Control negative, Lanes 3, Lane 4, Lane 5, Lane 6 and Lane 7: Positive Salmonellae invA gene.

environment under which chicken is slaughtered and increases the burden of foodborne infections in the people, and emphasizes the need to continuous education of the consumers on proper food handling and cooking practices to decrease the risk of transmission of Salmonella and other foodborne pathogens.

\section{Authors' Contributions}

NMA designed the study, collected and analyzed the samples, drafted and revised the manuscript.

\section{Acknowledgments}

Author is grateful for the help provided by all members of the Department of Food Hygiene, Faculty of Veterinary Medicine, Sohag University, Sohag, Egypt.

\section{Competing Interests} interests.

The authors declare that they have no competing

\section{References}

1. Del Rio, E., Panizo, M., Prieto, M., Alonso-Calleja, C. and Capita, R. (2007) Effects of various chemical decontamination on natural flora and sensory characteristics of poultry. Int. J. Food Microbiol., 115: 268-280.

2. Mulder, R.W. (1999) Hygiene during transport, slaughter and processing. In: Richardson, R.I. and Mead, G.C., editors. Poultry Meat Science. Poultry Science Symposium Series. Vol. 25. CABI Publishing, Massachusetts. p277-283.

3. El-Aziz, D.M.A. (2013) Detection of Salmonella typhimurium in retail chicken meat and chicken giblets. Asia
Pac. J. Trop. Biomed., 3: 678-681.

4. Uyttendaele, M.R., Debevere, J.M., Lips, R.M. and Neyts, K.D. (1998) Prevalence of Salmonella in poultry carcass and their products in Belgium. Int. J. Food Microbiol., 40: $1-8$.

5. Hernandez, T., Sierra, A., Rodriguez-Alvarez, C., Torres, A., Arevalo, M.P., Calvo, M. and Arias, A. (2005) Salmonella enterica serotypes isolated from imported frozen chicken meat in Canary Islands. J. Food Prot., 68(12): 2702-2706.

6. Todar, K. (2005) Salmonella and salmonellosis. Todar's Online Textbook of Bacteriology. (C) 2005 Kenneth Todar University of Wisconsin-Madison Department of Bacteriology, USA.

7. Li, R., Wang, Y., Shen, J. and Wu, C. (2013) Development of a novel hexa-plex PCR method for identification and serotyping of Salmonella species. Foodborne Pathog. Dis., 11: 75-77.

8. Chiu, C.H. and Ou, J.T. (1996) Rapid identification of Salmonella serovars in feces by specific detection of virulence genes, invA and $s p v C$, by an enrichment broth culture-multiplex PCR combination assay. J. Clin. Microbiol., 34: 2619-2622.

9. Darwin, K.H. and Miller, V.L. (1999) Molecular basis of the interaction of Salmonella with the intestinal mucosa. Clin. Microbiol. Rev., 12: 405-428.

10. Kauffmann, G. (1974) Kauffmann white scheme. J. Acta Pathol. Microbiol., 61: 385.

11. Shanmugasamy, M., Velayutham, T. and Rajeswar, J. (2011) Inv A gene specific PCR for detection of Salmonella from broilers. Vet. World, 4(12): 562-564.

12. Shah, D., Shringi, S., Besser, T. and Call, D. (2009) In: Liu, D., editor. Molecular Detection of Foodborne Pathogens. CRC Press, Taylor \& Francis Group. Florida, Boca Raton, USA. p369-389.

13. Ruban, S., Thyiageeswaran, M. and Sharadha, R. (2010) Isolation and identification of Salmonella spp from retail chickens by polymerase chain reaction. J. Microbiol. Res., 1(3): 106-109.

14. Akbar, A. and Kumar, A. (2013) Prevalence and antibiogram study of Salmonella and Staphylococcus aureus in poultry meat. Asia Pac. J. Trop. Biomed., 3(2): 163-168.

15. Karmi, M. (2013) Detection of virulence gene (inva) in Salmonella isolated from meat and poultry products. Int. J. Genet., 3(2): 07-12.

16. Suwit, C., Suvichai, R., Fred, U., Pakpoom, T. and Prapas, P. (2014) prevalence and antimicrobial resistance of salmonella isolated from carcasses, processing facilities and the environment surrounding small scale poultry slaughterhouses in Thailand. Southeast Asian J. Trop. Med. Public Health, 45(6): 1392-1400.

17. Pedro, H., Waldemir, S.A., Beatriz, D.F., Virginia, L.A., Dayse, L.A., Dalia, D.P., Elmiro, R.D. and Maria, H.C. (2016) Prevalence and fluoroquinolones resistance of Campylobacter and Salmonella isolates from poultry carcasses in Rio de Janeiro, Brazil. Food Control, 61: 243-247.

18. Alali, W., Gaydashov, R., Petrova, E., Panin, A., Tugarinov, O., Kulikovskii, A., Mamleeva, D., Walls, I. and Doyle, M.P. (2012) Prevalence of Salmonella on retail chicken meat in Russian federation. J. Food Prot., 75(8): 1469-1473.

19. Jianghui, Z., Yeru, W., Xiaoyu, S., Shenghui, C., Haibin, X., Baowei, Y., Jinlin, H., Guihua, L., Qian, C., Gang, Z., Qiuxia, C. and Fengqin, L. (2014) Prevalence and quantification of Salmonella contamination in raw chicken carcasses at the retail in China. J. Food Control, 44: 198-202.

20. Rodriguez, J., Rondón, I. and Verjan, N. (2014) Serotypes of Salmonella in broiler carcasses marketed at Ibague, Colombia. Braz. J. Poult. Sci., 17(4): 545-552.

21. Jarquin, C., Alvarez, D., Morales, O., Morales, A.J., López, B., Donado, P., Valencia, M.F., Arévalo, A., Muñoz, F., Walls, I., Doyle, M. and Alali, W. (2015) Salmonella on raw poultry in retail markets in Guatemala: Levels, antibiotic susceptibility, and serovar distribution. $J$. Food Prot., 9: 162-1769. 
22. Elgroud, R., Zerdoumi, F., Benazzouz, M., BouzitounaBentchouala, C., Granier, S.A., Frémy, S., Brisabois, A., Dufour, B. and Millemann, Y. (2009) Characteristics of Salmonella contamination of broilers and slaughterhouses in the region of Constantine (Algeria). Zoonoses Public Health, 56: 84-93.

23. Cretu, C., Floristean, V., Carp-Carare, M., Bradatan, G. and Isan, E. (2009) The Influence of $\mathrm{pH}$ and temperature on Salmonella spp. from fresh, chilled and frozen poultry carcasses. Cercetări Agronomice în Moldova, XLII(2): 79-84.

24. Nori, E.M. and Thong, K.L. (2010) Differentiation of Salmonella enterica based on PCR detection of selected somatic and flagellar antigen. Afr. J. Microbiol. Res., 4(9):
871-879.

25. Jennifer, D., Boddicker, B., Knosp, M. and Bradley, D.J. (2003) Transcription of the Salmonella invasion gene activator, hilA requires hilD Activation in absence of negative regulators. J. Bacteriol., 185(2): 525-533.

26. Ibrahim, W., Abd El-Ghany, W., Nasef, S. and Hatem, M. (2014) A comparative study on the use of real time polymerase chain reaction (RT-PCR) and standard isolation techniques for the detection of Salmonella in broiler chicks. Int. J. Vet. Sci. Med., 2(1): 67-71.

27. Herikstad, H., Motarjemi, Y. and Tauxe, R.V. (2002) Salmonella surveillance: Aglobal survey of public health serotyping. Epidemiol. Infect., 129: 1-8.

$* * * * * * * *$ 